\title{
Comparative Studies of Fusarium Wilt in Chickpea on Effect of Bio-agents and Essential Oils in Aspects of Cost Benefit Ratio
}

\author{
Deependra Singh Shekhawat $^{1 *}$, Shashi Tiwari ${ }^{2}$ and B. D. S. Nathawat ${ }^{1}$ \\ ${ }^{1}$ Plant Pathology, ARS, SKRAU, Bikaner, India \\ ${ }^{2}$ Department of Plant Pathology, SHUATS, Prayagraj, India \\ *Corresponding author
}

\section{A B S T R A C T}

Ke y w o r d s
Bio-agents,
Essential oil, Cost
benefit ratio,
Chickpea and Wilt
disease

\section{Introduction}

Chickpea (Cicer arietinum L.) is a bushy annual plant of the pea family, with short, hairy pods containing usually two seeds. Chickpea is the world's third most important pulse crop, after dry beans (Phaseolus vulgaris L.) and dry peas (Pisum sativum L.) (Vishwadhar and Gurha, 1998). Chickpea is valued for its nutritive seeds with high protein content (25.3-28.9\%) after dehulling (Hulse, 1991). India, accounts for $75 \%$ of world's chickpea production on 13.98 million ha area with production 137.3 lakh tonnes and productivity $982 \mathrm{~kg} / \mathrm{ha}$ (Haware, et al., 2016). Fusarium wilt is a serious disease of chickpea in India, Iran, Pakistan, Nepal, Burma, Spain, Tunisia and Mexico. It causes complete loss in grain yield if the disease occurs in the vegetative and reproductive stages of the crop (Haware and Nene, 1980; Haware et al., 1990; Halila and strange, 1996; Navas et al., 2000).This fungus, Fusarium oxysporiumf. sp. cicerisis primarily a soil borne pathogen; however, few reports indicated that it can be transmitted through seeds (Haware et al., 1978). 
The disease manifests as mortality of young seedlings (within 25 to 30 days after sowing) to wilt or death of adult plants (Haware et al., 1978). Seedlings that die due to wilt disease can be confused with other diseases of wilt complex, if not examined carefully. Fusarium wilt infected seedlings collapse and lie flat on the ground retaining their dull green color. Adult plants show typical wilt symptoms of drooping of petioles, rachis and leaflets.

The roots of the wilting plants do not show any external rotting but when split open vertically, dark brown discoloration of internal xylem is seen (Nene et al., 1991). Pods from the wilted plants look normal but seeds are generally smaller, wrinkled and discolored. Though such seeds can be detected visually, a normal looking seed harvested from wilted plants may also harbor the wilt pathogen. Seeds from wilted plants when mixed with the seeds from healthy plants may be responsible in introducing wilt in new areas. Management of Fusarium wilt of chickpea is difficult to achieve and no single control measure is fully effective.

The most effective and practical method of control worldwide is to use fungicides (Gupta et al., 1988) or resistant cultivars. However, the effectiveness of host resistances is curtailed by the occurrence of pathogenic races in Fusarium oxysporium f. sp. ciceris (Haware and Nene, 1982; Jimenez-Diaz et al., 1989; Jimenez-Gasco et al., 2004).

Therefore, integrated management strategies are the only solution to maintain plant health, including minimum use of chemicals for checking the pathogen population, encouragement of beneficial biological agents to reduce pathogen inoculum (Bendre and Barhate, 1998). The purpose of this study is to find out the best cost benefit ratio for suitable antagonists to manage the disease.

\section{Materials and Methods}

The field experiment was conducted during Rabi season at Central Research Farm, Department of Plant Pathology, Allahabad School of Agriculture, Sam Higginbottom University of Agriculture, Technology and Sciences, Prayagraj, U.P., entitled "Biological approaches against Wilt caused by Fusarium oxysporum f. sp. ciceriof Chickpea (Cicer arietinum L.)".The detail of the methods employed and materials used during the course of investigations are as follows-

\section{Climate}

Prayagraj is situated at $25.27^{\circ}$ North latitude $80.50^{\circ}$ East longitude and at an altitude of 98 meter above sea level. The climate is typically semi arid and sub tropical.

The maximum temperature reaches up to $47^{\circ}$ $\mathrm{C}$ in summer and drops down to $1.5^{\circ} \mathrm{C}$ in winters. Isolation will be made from rhizosphere or infected stem and pure culture will be procured.

Mass multiplication of $F$. oxysporum $f$. sp. ciceri

Pure culture of $F$. oxysporum f. sp. ciceriwas procured from Department of Plant Pathology, SHUATS, Prayagraj.

In laboratory all glass wares used were thoroughly cleaned with detergent, washed dried and sterilized at $150^{\circ} \mathrm{C}$ for $4 \mathrm{~h}$ and Potato Dextrose Agar (PDA) was used for isolation of fungus as method described by The petri dishes and pipettes were wrapped in clean paper and sterilized in hot air oven at a temperature of $150^{\circ} \mathrm{C}$ to $180^{\circ} \mathrm{C}$ for two to four hours.

For isolating and growing of pathogen $F$. oxysporum f. sp. ciceri, Potato Dextrose Agar 
(PDA) medium was used. The procedure for the preparation of medium was adopted as mentioned by Aneja, (2004).

\section{Material Required}

Agar $20 \mathrm{~g}$

Dextrose $20 \mathrm{~g}$

Peeled potatoes $200 \mathrm{~g}$

Distilled water $1000 \mathrm{ml}$

$\mathrm{pH}$ 5.5-6.5

\section{Procedure}

Weighed $200 \mathrm{~g}$ of peeled Potato gently with the help of weighing machine. It was boiled in $500 \mathrm{ml}$ of distilled water till potatoes were mashed easily by the finger.

Potato extract was extracted with the help of muslin cloth. Measured the amount of sieved extract on measuring cylinder and made it $1000 \mathrm{ml}$ by the addition of distilled water.

Again stared boiling of extract and added bit by bit Dextrose powder and Agar powder respectively. The PDA was transfer in the conical flask $(250 \mathrm{ml})$ for sterilization. It was kept for $30 \mathrm{~min}$ at $15 \mathrm{lbs}$ and $120 \pm 2^{0} \mathrm{C}$ temperature (Aneja, 2004). For further analysis and mass multiplication of Fusarium sp. slants was prepared.

\section{Isolation and identification of the pathogen}

Sample of infected root was randomly collected from experimental plot. Root was washed with tap water to removed soil particles and warp gently with the bloating sheet.

One present concentration of $\mathrm{HgCl}_{2}$ was used for surface sterilization of root. Small pieces of roots were cut with sharp blade under aseptic condition and plot on petri dishes which contend PDA. Inoculated petri dishes were incubated in B.O.D. After recommended period of incubation mycelium growth of pathogen was observed on the petri dishes. Single spore technique was applied for purification of Fusarium sp. and pure culture of Fusarium sp. was transferred in several slants for further analysis.

\section{Procedure for mass multiplication of $F$. oxysporum f. sp. ciceri}

The chickpea seeds were soaked partially for overnight and then spread on the clean blotting paper for air drying. About $250 \mathrm{gm}$. of seeds of chickpea were filled in each 1000 $\mathrm{ml}$ flask and autoclaved for 30 minutes at 15 lbs. psi pressure.

The mycelium bit of pure culture of $F$. oxysporum f. sp. Cicero was inoculated under aseptic condition in those flask containing grains and incubated at $28 \pm 2{ }^{\circ} \mathrm{C}$ for 10 days.

Meanwhile flasks were shaken to avoid clumping of grains and to facilitate early growth of fungus. These mass inoculums were spread in the experimental sick plot before two week of sowing (Aneja, 2004).

\section{Sowing chick pea seeds into inoculated plot}

The experiment was conducted in Randomized block design (RBD), using 2x2 $\mathrm{m}$ plot size with three replications. Sowing date was 18 December, 2018. The sowing was done row to row and plant to plant spacing with of $30 \times 10 \mathrm{~cm}$.

\section{Post planting operation}

Irrigation, weeding, earthing, thinning, etc. were carried out routinely for the proper growth of the crop. 


\section{Application of Treatment}

\begin{tabular}{|c|c|c|c|}
\hline Symbols & Treatments & $\begin{array}{c}\text { Method of } \\
\text { Application }\end{array}$ & References \\
\hline $\mathbf{T}_{\mathbf{0}}$ & Control & - & - \\
\hline $\mathbf{T}_{\mathbf{1}}$ & Neem oil & Seed treatment & Singh et al., (2016) \\
\hline $\mathbf{T}_{\mathbf{2}}$ & Eucalyptus oil & Seed treatment & Dawar et al., (2007) \\
\hline $\mathbf{T}_{\mathbf{3}}$ & Trichoderma viride & Seed treatment & Chand et al., (2009) \\
\hline $\mathbf{T}_{\mathbf{4}}$ & Pseudomonas sp. & Seed treatment & Shrivastava et al., (201 \\
\hline $\mathbf{T}_{\mathbf{5}}$ & Neem oil $+T$. Viride & Seed treatment & Chakraborty et al., (20 \\
\hline $\mathbf{T}_{\mathbf{6}}$ & T. viride + Neem oil + Pseudomonas $s p$. & Seed treatment & - \\
\hline $\mathbf{T}_{\mathbf{7}}$ & T. viride +Neem oil+ Eucalyptus oil & Seed treatment & - \\
\hline
\end{tabular}

\section{Results and Discussion}

The data presented in Table revealed that maximum yield of $28.75 \mathrm{q} / \mathrm{ha}$ with cost benefit ratio 1:2.89 was obtained with Neem oil $+T$. viride $+P$. fluorescens as seed treatment. Next effective treatment was Neemoil+
Eucalyptus Oil $+T$. viride seed treatment with effective CB $(1: 2.31)$, followed by Neem oil+ $T$. viride seed treatment with CB $(1: 2.30), T$. viride seed treatment with $\mathrm{CB}$ (1:2.25), neem oil seed treatment with CB (1:2.02), Pseudomonas fluorescens seed treatment with CB (1:1.90) and eucalyptus oil seed treatment with $\mathrm{CB}$ (1:1.64) over the control.

Table.1 Economics of treatments

\begin{tabular}{|c|c|c|c|c|}
\hline S.No & Treatment & $\begin{array}{c}\text { Rate } \\
\text { Seed treatment }\end{array}$ & $\begin{array}{c}\text { Cost of } \\
\text { Chemical }\end{array}$ & $\begin{array}{c}\text { Cost } \\
\text { of Treatment }\end{array}$ \\
\hline 01 & $\begin{array}{c}\mathbf{T}_{\mathbf{1}} \\
\text { Neem oil }\end{array}$ & $50 \mathrm{ml} / \mathrm{kg}$ seed & 250Rs/lt & $1250 /-$ \\
\hline 02 & $\begin{array}{c}\mathbf{T}_{\mathbf{2}} \\
\text { Eucalyptus oil }\end{array}$ & $50 \mathrm{ml} / \mathrm{kg}$ seed & 1000Rs/lt & $5000 /-$ \\
\hline 03 & $\begin{array}{c}\mathbf{T}_{\mathbf{3}} \\
\text { T. viride }\end{array}$ & $50 \mathrm{ml} / \mathrm{kg}$ seed & 70Rs/lt & $350 /-$ \\
\hline 04 & $\begin{array}{c}\mathbf{T}_{\mathbf{4}} \\
\text { P. fluorescens }\end{array}$ & $50 \mathrm{ml} / \mathrm{kg}$ seed & $100 \mathrm{Rs} / \mathrm{Kg}$ & $500 /-$ \\
\hline 05 & $\begin{array}{c}\mathbf{T}_{\mathbf{5}} \\
\text { Neem oil+ } T \text {. viride }\end{array}$ & $\begin{array}{c}50 \mathrm{ml} \text { of oil } \\
+5 \mathrm{gm} / \mathrm{kg} \text { seed }\end{array}$ & 320Rs./Kg & $1280 /-$ \\
\hline 06 & $\begin{array}{c}\mathbf{T}_{\mathbf{6}} \\
\text { Neem oil+ T. viride }+ \\
\text { P. fluorescens }\end{array}$ & $\begin{array}{c}50 \mathrm{ml} \text { of oil } \\
+5 \mathrm{gm} / \mathrm{kg} \text { seed }\end{array}$ & $420 \mathrm{Rs} / \mathrm{Kg}$ & $1510 /-$ \\
\hline 07 & $\begin{array}{c}\mathbf{T}_{7} \\
\text { Neemoil+Eucalyptus } \\
\text { Oil }+T \text {. viride }\end{array}$ & $\begin{array}{c}50 \mathrm{ml} \text { of oil } \\
+5 \mathrm{gm} / \mathrm{kg} \text { seed }\end{array}$ & $\begin{array}{c}1320 \text { Rs./ } \\
\text { Kg. }\end{array}$ & $4030 /-$ \\
\hline 08 & $\begin{array}{c}\mathbf{T}_{\mathbf{0}} \\
\text { Control }\end{array}$ & ----------- & ------------ & \\
\hline
\end{tabular}


Table.2 Comparative effect of Bio-agents and essentiall oils on Cost Benefit Ratio

\begin{tabular}{|c|c|c|c|c|c|c|c|c|}
\hline S.No. & Treatment & $\begin{array}{l}\text { Yield } \\
\text { of } \\
\text { q/ha }\end{array}$ & $\begin{array}{c}\text { Cost of } \\
\text { yield }\end{array}$ & $\begin{array}{l}\text { Total cost } \\
\text { of } \\
\text { yield (Rs.) }\end{array}$ & $\begin{array}{l}\text { Common } \\
\text { Cost } \\
\text { (Rs.) }\end{array}$ & $\begin{array}{l}\text { Treatment } \\
\text { cost } \\
\text { (Rs.) }\end{array}$ & $\begin{array}{l}\text { Total } \\
\text { cost }\end{array}$ & $\begin{array}{l}\mathrm{C}: \mathrm{B} \\
\text { ratio }\end{array}$ \\
\hline 01 & $\begin{array}{c}\mathbf{T}_{\mathbf{1}} \\
\text { Neem oil }\end{array}$ & 20.04 & $\begin{array}{l}4500 \\
\mathrm{Rs} / \mathrm{q}\end{array}$ & 90180/- & 43200/- & $1250 /-$ & $44450 /-$ & $1: 2.02$ \\
\hline 02 & $\begin{array}{c}\mathbf{T}_{\mathbf{2}} \\
\text { Eucalyptus oil }\end{array}$ & 17.62 & $\begin{array}{l}4500 \\
\text { Rs/q }\end{array}$ & 79290/- & $43200 /$ & 5000/- & $48200 /-$ & $1: 1.64$ \\
\hline 03 & $\begin{array}{c}\mathbf{T}_{3} \\
\text { T. viride }\end{array}$ & 21.79 & $\begin{array}{r}4500 \\
\text { Rs/q }\end{array}$ & 98055/- & $43200 /$ & $350 /-$ & $43550 /-$ & $1: 2.25$ \\
\hline 04 & $\begin{array}{c}\mathbf{T}_{\mathbf{4}} \\
\text { P. fluorescens }\end{array}$ & 18.54 & $\begin{array}{l}4500 \\
\text { Rs/q }\end{array}$ & 83430/- & $43200 /$ & $500 /-$ & $43700 /-$ & $1: 1.90$ \\
\hline 05 & $\begin{array}{c}\mathbf{T}_{\mathbf{5}} \\
\text { Neem oil+ } T \text {. Viride }\end{array}$ & 22.75 & $\begin{array}{l}4500 \\
\text { Rs/q }\end{array}$ & $102375 /-$ & $43200 /$ & $1280 /-$ & 44480/- & $1: 2.30$ \\
\hline 06 & $\begin{array}{c}\mathrm{T}_{6} \\
\text { Neem oil+ T. viride } \\
+ \text { P. Fluorescens }\end{array}$ & 28.75 & $\begin{array}{c}4500 \\
\text { Rs/q }\end{array}$ & 129375/- & $43200 /$ & 1510/- & 44710/- & $1: 2.89$ \\
\hline 07 & $\begin{array}{c}\mathrm{T}_{7} \\
\text { Neemoil+Eucalyptus } \\
\text { Oil }+T \text {. Viride }\end{array}$ & 24.25 & $\begin{array}{l}4500 \\
\text { Rs/q }\end{array}$ & 109125/- & $43200 /$ & 4030/- & 47230/- & $1: 2.31$ \\
\hline 08 & $\begin{array}{c}\mathrm{T}_{0} \\
\text { Control }\end{array}$ & 15.58 & $\begin{array}{l}4500 \\
\text { Rs/q }\end{array}$ & 70110/- & $43200 /$ & --------- & 43200/- & $1: 1.62$ \\
\hline
\end{tabular}

The present investigation indicates that application of Neem oilt $T$. viride $+P$. fluorescens with seed treatment can be used as an effective treatment of wilt disease.

\section{References}

Aneja, K.R. (2004).Experiments in Microbiology, Plant Pathology and Biotechnology. Fourth Edition. New Age International (P) Ltd., Publishers, New Delhi. Pg. 75-82.

Bendre, NJ, BG Barhate. 1998. A souvenir on Disease Management in Chickpea. M.P.K.V., Rahuri during 10th Dec. 1998.

Chakraborty, M. R., Chatterjee, N. C. and Quimio, T. H. (2009).Integrated management of fusarial wilt of egg plant (Solaum melongena) with soil solarisation. Micologia Aplicada International; 21(1): Pg. 25-36.
Chand, H. and Khirbat, S. K. (2009).Chickpea wilt and its management - A review. Agricultural Review, 30(1): 1 - 12.

Dawar, S., Younus, S., Tariq, M. and M. Zaki, J. (2007).Use of Eucalyptus sp., in the control of root infecting fungi on mung bean and chick-pea. Pak. J. Bot., 39(3). Pg. 2-4.

Gupta, RP, RP Katiyar, and DP Singh. (1988). Seed treatment with Bavistin and Rhizobium and its effect on wilt incidence, nodulation and yield of chickpea. Pesticides 22: 9-10.

Halila, M.H.; Strange, R.N. (1996) Identification of the causal agent of wilt of chickpea in Tunisia as Fusarium oxysporum f. sp. ciceri race 0. Phytopathol. Mediterr. 35, 67-74.

Haware, M.P. (1990). Fusarium wilt and other important diseases chickpea in the Mediterranean area. In Present Status and Future Prospects of Chickpea Crop 
Production and Improvement in the Mediterranean Countries; Saxena, M.C., Cubero, J.I.,Wery, J., Eds.; CIHEAM: Zaragoza, Spain,; pp. 6164.

Haware, M.P. (1990). Fusarium wilt and other important diseases chickpea in the Mediterranean area. In Present Status and Future Prospects of Chickpea Crop Production and Improvement in the Mediterranean Countries;Saxena, M.C., Cubero, J.I.,Wery, J., Eds.; CIHEAM: Zaragoza, Spain,; pp. 6164.

Haware, M.P.; Nene, Y.L. (1980) Influence of wilt and different growth stages on yield loss in chickpea. Trop. GrainLegum. Bull. 19, 38-40.

Haware, M.P.; Nene, Y.L. (1982).Races of Fusarium oxysporum f.sp. ciceri. Plant Dis. 66, 809-810.

Haware, M.P.; Nene, Y.L.(1978) Rajeshwari,

R. Eradication of Fusarium oxysporum

f. sp. ciceri transmitted inchickpea seed. Phytopathology, 68, 1364-1367.

Hulse, JH. (1991). Nature, composition and utilization of grain legumes. P: 11-27. In: Uses of tropical Legumes: Proceedings of a Consultants' Meeting, 27-30 March 1989, ICRISAT Center. ICRISAT, Patancheru, A.P. 502 324, India.

Landa, B.B.; Navas-Cortés, J.A.; JiménezDíaz, R. M. (2004) Integrated management of fusarium wilt of chickpea with sowing date, host resistance, and biological control. Phytopathology 94, 946-960.

Navas-Cortés, J.A.; Hau, B.; Jiménez-Díaz,
R.M. (2000).Yield loss in chickpeas in relation to development of Fusarium wilt epidemics. Phytopathology 90, 1269-1278.

Navas-Cortés, J.A.; Hau, B.; Jiménez-Díaz, R.M. (1998) Effect of Sowing Date, Host Cultivar, and Race of Fusarium oxysporum f. sp. ciceris on Development of Fusarium Wilt of Chickpea. Phytopathology 88, 13381346.

Nene, YL, MV Reddy, MP Haware, AM Ghanekar and KS Amin, (1991). Field diagnosis of chickpea diseases and their control. In: Information Bulletin no. 28. ed. by International Crops Research Institute for the Semi-Arid Tropics, Patancheru, India.

Singh, J., Ratna, V. and Singh, N. (2009). Management of wilt in chick pea. Annals of Plant Protection Sciences. 17(1): 248-249.

Srivastava, R., Khalid, A., Singh, U.S. And Sharma, A.K. (2010).Evaluation of arbuscular mycorrhizal fungus, fluorescent Pseudomonas and Trichoderma harzianum formulation against Fusarium oxysporum f. sp. Lycopersici for the management of tomato wilt. Biological Control 53: 2431.

Vishwa Dhar, Gurha SN. (1998). Integrated Management of Chickipea Diseases. Integrated Pest and disease management. Rajeev K, Upadhyay KG, Mukerji BP, Chamola and Dubey OP (eds.) APH Publishing Co., New Delhi. (India). P-249.

\section{How to cite this article:}

Deependra Singh Shekhawat, Shashi Tiwari and Nathawat, B. D. S. 2021. Comparative Studies of Fusarium Wilt in Chickpea on Effect of Bio-agents and Essential Oils in Aspects of Cost Benefit Ratio. Int.J.Curr.Microbiol.App.Sci. 10(01): 2237-2242. doi: https://doi.org/10.20546/ijcmas.2021.1001.257 